\title{
Why ASEAN is Cooperating in the Education Sector?
}

\author{
Jan Gawron' 1
}

\begin{abstract}
Over the last few years ASEAN member states have begun collaborating more tightly in the tertiary education sector, which has led to a cooperation agreement with the European Union to help harmonize and lift the overall standard of tertiary education in the region. However, the broader question is - why is that the case? Education is not considered a classical field of regional integration, and this chapter seeks to analyze various sources - which include references from elitist circles, as well as the public sphere - in order to identify the motivation for cooperation in the education sector through qualitative content analysis. The analysis is based on a theoretical framework, which incorporates both a neofunctionalist approach and a norm diffusion approach which show that the predominant factors behind this cooperation process are economic.
\end{abstract}

Keywords: ASEAN, Cooperation, Education Sector

\footnotetext{
1 Project Assistant at the Southeast Asian Studies Program, University of Freiburg, Germany. Coressponding e-mail: jan.gawron@politik.uni-freiburg.de
} 


\section{Introduction}

"'Looking at all the challenges that our education system has faced, I don't think we're going anywhere soon if we don't take action right now,' Dr Van Chanpheng, deputy director general of higher education at the Ministry of Education, told University World News" (Keo, 2012).

In January 2015 the Association of Southeast Asian Nations (ASEAN) and the European Union (EU) agreed on a cooperation in the field of tertiary education. It aims on sharing experiences of the European harmonization process in order to help propel tertiary education further in ASEAN (Delegation of the EU to Indonesia, Brunei Darussalam and ASEAN, 2015; ASEAN University Network, 2015). Besides this recently stated cooperation, various steps towards integration in the education sector have already been taken: the establishment of the ASEAN University Network, ASEAN Education Ministers Meeting on a regular basis since 2006, the establishment of a quality assurance mechanism (AUN-QU) or the AUN-ASEAN Credit Transfer System, to name only a few (ASEAN Work Plan on Education, 2013). This development, combined with the fact that even cooperation with the EU is pursued, allows for the assumption that a shared interest for further and deeper collaboration in the education sector is present. This appears especially interesting when taking into account that education policy is not a classical field of regional cooperation. Additionally, not much work has been done looking into this rather new phenomenon. Hence, this chapter aims on investigating these circumstances and eventually pointing out key motivations and justifications for cooperation in the field of education among ASEAN members.

Therefore, a sample of documents from different sources will be analyzed along three hypotheses, carved out using both deductive and inductive approaches in order to find motivations and justifications for regional cooperation among ASEAN members. In doing so, H1: "Education Integration initiatives are spillovers from the economic sector" can be confirmed, whereas H2a: "Integration in the education sector is a result of political learning" and H2b: "Integration in the education sector is a result of appropriate acting" cannot be verified. The findings allow to confirm the central research question "Does economic integration create functional needs for education 
integration?". $60 \%$ of the text passages which were allocated to the underlying category system fit into categories which support hypothesis $\mathrm{H} 1$ and subsequently confirm the central research question. That is, I argue that ASEAN member states strive to cooperate in the sector of education for mainly economic reasons in moving closer to meeting the central requirements of a single market; "In particular, the Leaders agreed to hasten the establishment of the ASEAN Economic Community by 2015 and to transform ASEAN into a region with free movement of goods, services, investment, skilled labour, and freer flow of capital" (ASEAN, 2008, p.5). The motivation for heightened cooperation in the region serves more to contribute toward a freer flow of skilled labor to foster economic performance than anything else. It is as James Carville, campaign strategist of Bill Clinton's successful presidential campaign in 1992 famously put it - about "the economy, stupid."

\section{Historical Review}

When looking at the early stages of regional integration in Southeast Asia, which was founded in 1967 following Indonesia's konfrontasi against Malaysia and was primarily meant "to alleviate intra-ASEAN tensions, to reduce the regional influence of external actors, and to promote the socio-economic development of its members" (Narine, 2008, p. 6), integration in the education sector cannot be considered a logical or even necessary development. Now, ASEAN consists of ten member states and aims on bringing peace and stability to the region (Narine, 2008, p. 6). Additionally, economic growth, social welfare enhancement and tighter collaboration in sectors of shared interest are aspired (ASEAN Secretariat, 1967). Likely due to the great heterogeneity of the member states, the integration process has not always been smooth and linear.

In order to face and eventually overcome this complexity, the Treaty of Amity and Cooperation (1976) was implemented (ASEAN Secretariat, 1976). It describes a certain way of behavior and communication when interacting with each other. It centers around the strict compliance with the norms of non-interference with domestic politics of other member states, informal conflict management and respect for territorial integrity of all member states, the abstinence of direct confrontation with other member states and also the pursuit of unity and harmony (Busse, 1999, p. 39; Narine, 2008, p. 8; Rother, 2004, p. 29). During the course of the Asian Financial 


\section{Jan Gawron}

Crisis 1997/98, however, the so far developed cooperation system, which was founded on these norms, turned out to not be efficient enough. As a response to this obvious shortage of room for maneuver (Narine, 2008, p. 18; Rüland, 2012, p. 251), the development of the ASEAN Vision 2020 as well as the establishment of the ASEAN Community 2015 was announced.

The ASEAN Community rests upon three central pillars: the Political-Security Community (APSC), the Socio-Cultural Community (ASCC) and the Economic Community (AEC), (see Declaration of ASEAN Concorde II, in ASEAN Secretariat, 2003). With the introduction of ASEAN Community 2015 regional cooperation in the economic sector was significantly broadened and was expanded to the social-cultural sector. Originally the start of the ASEAN Community 2015 was set to January 1st, 2015, but was then postponed in 2012 to the end of 2015 (Ashayagachata, 2012). As the AEC - the framework for economic integration measurements - is included in the ASEAN Community, it was subsequently postponed as well. That contributed to the rising critical voices towards the overall well-being of the new common market, which had been ever present from the early stages of planning until the finalization of the implementation process (Frenquest, 2015). Above all, the member states' disparate education situation and the subsequent performance level of the AEC were subject to criticism.

\section{Theoretical Framework}

The connection of economic integration as one thematic complex and education integration as another, appears to be a valid starting point for the investigation on justifications and motivations for joint efforts to further integrate in the field of education. This is emphasized by the fact that this discussion is not only present in the public sphere but also in the scientific community; Chia et al., (2009, p. 53) state in their edited analysis of the AEC the necessity of free movement of skilled workers and the therefore needed regional education standards. Still, this is a very new and ongoing phenomenon and subsequently not much research on the matter has yet been produced. ${ }^{2}$ That is, no commonly accepted baseline for a theoretical approach can be identified and therefore has to be developed independently. For this reason, a

${ }^{2}$ For a brief overview on education research in Southeast Asia, see: Feuer \& Hornidge, 2015; Hawkins, 2012; Koh, 2007; Neubauer, 2012. 
deductive approach based on established theories of regional integration, and ASEAN research, respectively, is chosen. Here, Neofunctionalism (NF) as a classical theory of regional integration is suggested. Deducted from this theoretical approach, the central research question is derived: "Does economic integration create functional needs for education integration?" Taking into account that different variables might also be in play, the results of this analysis will additionally be contemplated through the perspective of norm diffusion and later contrasted with the neofunctionalist perspective.

\section{Neofunctionalism}

Deriving from idealist thinking and inspired from the belief that state's aggressive egoistic actions can be overcome, Functionalism was developed (Conzelmann, 2006, p. 157). Looking at the shipwrecking of the League of Nations, Functionalism postulates cooperation "from below", which is to decrease relevance of military power and enhances the possibility for peaceful relations at the same time. This means cross-border cooperation mostly in the low politics sector - in contrast to elite-driven cooperation "from above" (Conzelmann, 2006, p. 158). The appeal to cooperate comes from interdependency, meaning reciprocal dependencies between nation states (Keohane \& Nye, 1977). Military power then loses relevance in the light of interdependency and the "long shadow of the future", and additional trust in cooperation can be achieved through iteration. Therewith the game theory cooperation dilemma can be overcome and a way to strive for absolute gains can be paved (Schimmelfennig, 2008, p. 95). This cooperation then enables further cooperation on other issues (ramification). That is, the institutional design follows functional appeals; "form follows function" (Conzelmann, 2006, p. 158).

Neofunctionalism, an evolution of Functionalism, shifts its focus from "formulating recommendation for actions" to "intersubjectively comprehensible analysis of real world integration processes" (Conzelmann, 2006, p. 163). Integration is defined as a process, which leads to a certain feeling of community, common institutions and actions, as well as a long term expectation of peaceful change for a group of individuals within a specific territory (Deutsch et al., 1957, p. 5; Dougherty \& Pfaltzgraff, 2001, p. 510). Neofunctionalism, most notably coined by Ernst Haas, asks how economic cooperation could turn into political cooperation and is more a "social 


\section{Jan Gawron}

scientific analysis" compared to Functionalism (Conzelmann, 2006, p. 163). Neofunctionalism is largely developed around the empirical example of the European integration project. That becomes obvious through the emphasis of development of a "political community" and supranational organs (Conzelmann, 2006, p. 164). Central to this theoretical strand is the "spillover" concept (Haas, 1958, p. 238; Lindberg, 1963, p. 10) as a dynamic variable. The idea here is, that technical cooperation in one sector spills over to neighboring sectors, as this is likely to reduce costs (Conzelmann, 2006, p. 166). That is, political integration follows economic cooperation immediately and subsequently Haas points to the "expansive logic of sectoral integration" (Haas, 1958, p. 311). This sectoral integration eventually extends to higher political integration (Conzelmann, 2006, p. 166; Haas, 1958, p. 292; Rosamond, 2005, p. 244). Furthermore, the distinction between integration as a status quo and integration as a process is important. Haas describes integration as a process and subsequently incorporates the dynamic spillover. To sum up: "Without inclusion of neighboring sectors, expected welfare gains through cross-border cooperation in the original sector cannot be achieved permanently or completely" (Conzelmann, 2006, p. 167).

It is also to be noted that Neofunctionalism also takes social groups and supranational bureaucracies into account (Dougherty \& Pfaltzgraff, 2001, p. 511). In Haas' eyes this automatically leads to a steady integration process (Haas, 1961, p. 268). This automatism, however, was subject to major criticism and was later taken back (Conzelmann, 2006; Lindberg \& Scheingold, 1970; Schmitter, 2004). Also, the empirical focus on the European integration project has been criticized (Mattli, 2005), as well as overvaluing functional needs and the neglect of national interests. In sum, Neofunctionalism has been highly criticized for being too "optimistic" towards linear integration processes (Conzelmann, 2006; Lindberg \& Scheingold, 1970; Schmitter, 2004).

\section{Neofunctionalism and ASEAN}

When looking at the ASEAN area through a neofunctionalist perspective, a few shortages and limitations can be revealed with regard to its application. Built around the European integration project, NF perceives democratic pluralism during regional decision-making processes (Kim, 2014, p. 379). However, most of ASEAN member states are not democracies. Additionally, no member state is considered "free" 
according to the Freedom House Index. Six states are listed as "not free" and four as "partly free". ${ }^{3}$ Another limitation is NF's emphasis on the role of civil society groups which pressure the government. In Europe those are mainly economic interest groups (Kim, 2014, p. 383). Those type of groups, however, do not play a significant role in ASEAN's decision making process. The integration process in ASEAN is much more an elite-driven project, which is only hardly under institutional influence of economic interest groups (Ravenhill, 2008, p. 483). Furthermore, that applicability of the concept "form follows function" needs to be questioned here. Kim concludes that very often integration steps in ASEAN follow the very opposite logic. Kim argues that decisive steps are taken during meetings of state leaders in order to support their own interests and not because economical appeals in one sector made deeper cooperation necessary in another sector $(2014$, p. 381).

Even in light of these limitation NF still holds a certain value when analyzing integration processes in ASEAN. NF highlights the importance of socialization among the elites (Dougherty \& Pfaltzgraff, 2001, p. 516; Kim, 201, p. 378). Not only the European Union but also ASEAN can be described as an elite project (Kim, 2014, p. 378). This socialization occurs during common decision-making procedures in ASEAN, which is largely driven by expansion of regional cooperation with respect to sovereignty, strong national interests and the explicit refusal of supranational bodies. At this point NF is able to explain how and under which circumstances the integration process is developing using its argument of elite socialization (Kim, 2014, p. 378). It is also worth taking a look at the heart of neofunctionalist thinking: the spillover. Generally, NF concentrates on political integration that is derived from economic cooperation. Although this logic might not be fully applicable to every step of ASEAN's integration process, the idea of the spillover should not be overlooked completely especially with regard to the central research question and the relationship between economic entanglements and education integration.

In summary, it can be said that NF, which was clearly built around the European integration project, has its limitations when applying it to the case of ASEAN. Nevertheless, NF contains several components - first and foremost the functional logic

\footnotetext{
${ }^{3}$ Data taken from https://freedomhouse.org/regions/asia-pacific\#.VYP8God1pdf. Not free: Brunei Darussalam, Cambodia, Lao PDR, Myanmar, Thailand, and Vietnam. Partly free: Indonesia, Malaysia, The Philippines, Singapore.
} 
of the spillover - which justify an analysis of aspects of ASEAN's integration efforts through this perspective. However, it is acknowledged that also different, nonfunctional variables might be essential to the integration efforts in the education sector. In order to take this possibility into account and to strengthen the following discussion, norm-diffusion processes will also be considered.

\section{Norm Diffusion}

Another potential problem of Neofunctionalism when connected to qualitative content analysis could be the so-called "rhetoric-action-gap" (Jetschke \& Rüland, 2009). It describes the discrepancy between speech and resulting action. ${ }^{4} \mathrm{~A}$ second theoretical approach, namely norm diffusion research, will be introduced to expand the theoretical frame work in order to tackle this potential problem. Especially third generation norm diffusion approaches operate on the rhetoric-level and subsequently present a good opportunity to review hypotheses deriving from neofunctionalist argumentative logic from a reflexivist's perspective. Therewith it contributes to a more profound answer to the central research question.

The empirical starting point is the observation of processes of adaption, imitation and reproduction of norms within the international system. It was introduced to the field of international relations through the research on Europeanization at the beginning of the 21st century (Börzel \& Risse, 2000; Radaelli, 2000). Within norm diffusion research, three generations can be identified (Archaya, 2009). Influential concepts for the first generation are the Life Cycle Model (Finnemore \& Sikking, 1998), the Boomerang Model (Keck \& Sikking, 1998), as well as the Spiral Model (Risse, Ropp \& Sikking, 1999). These approaches have later been criticized for their Western-based perspective and the passiveness of the norm recipients (Acharya, 2009, p. 14). The second generation takes local, norm-receiving structures into account in order to deduce the hypothesis of cultural fit (Acharya, 2009). This generation mostly focuses on Europeanization (Börzel \& Risse, 2000, 2009; Radaelli, 2000).

\footnotetext{
4"Over the past few days I have had the opportunity to meet a few high-profile people, and it's been interesting to listen to them speak, but at the same time frustrating that actions don't always match words." (The Bangkok Post, 2013).
} 
The third generation decouples itself from the concentration on Western-based norm agents and reacts to the lasting criticism regarding the focus on the West and the passive local actors. The introduction of the premises that local actors react differently to incoming norms enhances the analytical framework. Thus, norm recipients are treated as active actors and their room for maneuver is put in the spotlight (Acharya, 2009, p. 14). Additionally, a new form of flexibility is created, which allows for more detailed analyzation of norm diffusion processes between the two poles of outright rejection and full transformation. Four different types of norm diffusion processes can be observed (Rüland, 2012). According to that, norms can firstly be fully rejected (see "Asian Value Debate" Rüland, 2012, p. 250). Norms can secondly be adopted rhetorically (isomorphic adaption). That means a formal adoption of institutional or organizational structures or terminology while local identities remain unchanged.

These strategies usually serve to secure legitimacy or pacification of normative pressure deriving from the international community (Di Maggio \& Powell, 1982; Rüland, 2012). Thirdly, external norms can combine themselves with already existing norms and create a fusion (localization). The prevailing set of rules, which are deeply rooted in the society - the so called cognitive prior - are not meant to be substituted completely in this case. Through the participation of local norm entrepreneurs in the norm diffusion process and the combination of local and external norms, local identities can partially change (Archaya, 2009). Fourthly, norms can be fully adopted and internalized (Radaelli, 2000; Rüland, 2012).

Not only has the degree of identical change had to be considered but also the activator for such a change. Normative change can arise step by step, in a discursive interplay of affected actors, or as a reaction to an external shock (Rüland, 2012, p. 250). Furthermore, two types of diffusion mechanisms can be observed. On the one hand diffusion through coercion; for example by a hegemonic power or an international organization. On the other hand, voluntary diffusion can be contemplated at this point. This voluntary diffusion can utilize different mechanisms, depending on the theoretical perspective. Rational-choice Institutionalism follows a rationalist approach and the sociological Institutionalism follows a reflexive, or cognitive approach, respectively. 
The rational approach follows the logic of rational acting, meaning a cost-benefit calculation as a reaction to either positive or negative appeals through diffusion. A positive appeal could be the prospect of financial or technical aid. Negative would be potential sanctions (Börzel \& Risse, 2009, p. 10). Diffusion is then related to political learning (Braun \& Gilardi, 2006, p. 306) Learning can then be a result of either functional pressure or competition; institutional arrangements which make others better are adopted.

Reflexive, or cognitive approaches follow the logic of appropriate acting. Actors aim to meet social standards and principles. Hence, norms do not diffuse as result of competition but because an external norm satisfies standards of appropriateness. Essential for local actors, meaning norm recipients, is, to secure legitimacy and to ensure socialization within the international system here. These two approaches are usually separated. According to Jetschke \& Lenz (2011), however, legitimacy can be generated through learning and the search for legitimacy and appropriateness can, in turn, contain learning (bounded learning).

\section{Norm Diffusion and ASEAN}

It has already come to light that initial approaches of norm diffusion offer explanations for integration processes in ASEAN. After the Asian Financial Crisis $1997 / 98$, forms of rational learning could be observed. In that case, the deeper cooperation in the economic sector facilitated through the founding of the ASEAN Economic Community (AEC) can be seen as a result of functional needs for institutional adjustments modeled after the European common market. This alteration of economic cooperation is an obvious product of rational learning (Jetschke \& Murray, 2012).

Also, processes of appropriate acting can be found with regard to central parameters which are decisive for the international acknowledgement of states. That is, an at least rhetorical shift towards central norms such as democratizing, good governance and the recognition of human rights can be observed in the ASEAN Charter ("people-oriented regionalism", Rüland, 2012, p. 238) - which was drafted in ASEAN Charter 2007 (ASEAN Secretariat, 2007). This shift cannot be fully explained with functional needs to adopt institutional arrangements which are shaped after EUinstitutions and ideas (Jetschke \& Murray, 2012, p. 181). 


\section{Research Design}

Based on neofunctionalist assumptions the first hypothesis is derived: H1: "Education Integration initiatives are spillovers from the economic sector". In that sense, economic integration efforts would lead to functional appeals for political integration. This question - and also the general suitability of NF in the context of ASEAN - will be analyzed on the basis of the evaluated material. In order to test H1 and also to offer an additional theoretical framework to the neofunctional logic, two hypotheses - one following rationalist thinking and one following reflexive thinking will be deduced from norm diffusion research.

H2a: "Integration in the education sector is a result of political learning."

H2b: "Integration in the education sector is a result of appropriate acting."

The examination of the material and the following discussion about these two hypotheses will be limited to references of the European integration project. The EU is presumed to be the state-of-the-art integration project and is subsequently very well suited as a reference point for processes of learning and diffusion. As it has already been mentioned above, this chapter aims on pointing out justifications and motivations for the ongoing integration process in the education sector. The central research question on functional needs from the economic sector shall then be answered within these parameters. A prerequisite for this undertaking is the evaluation and structuring of articulated motivations and justifications available in the material. Therefore, a content-structured content analysis is proposed (see Kuckartz, 2012; Mayring, 2010; Schreier, 2012). The main aim of this method is the "analysis of material, which derives from any form of communication" (Mayring, 2010, p. 11). The material is analyzed along a theory-based question or problem; "the results are interpreted based on the underlying theoretical framework and also each analytical step is guided by theoretical considerations" (Mayring, 2010, p. 13).

Additionally, the material will be processed according to Mayring's (2010, p.13) frequency analysis. That means the counting of the previously structured elements in order to compare them to each other and generate deeper insight into the material. The connection of content-structured content analysis and frequency analysis enables the development of not only a distinct and comprehensible overview of the material in comparison to a strictly qualitative approach but at the same time also a deeper understanding of the material, as opposed to a purely quantitative approach such as 


\section{Jan Gawron}

simply counting words. The concrete modus operandi is oriented after Schreier's suggestions for a content-structured content analysis (Schreier, 2014, p. 24), as well as Mayring's approach to a frequency analysis (Mayring, 2010, p. 15). The central research question is derived from the prevailing context of ASEAN's integration efforts, as well as from Neofunctionalism; does integration in the economic sector lead to functional appeals for integration in the education sector?

In order to find answers to this question, material from three thematic clusters will be analyzed using a content-structured content analysis in combination with a frequency analysis. The first cluster contains documents coming from the respective national states and is therefore referred to as "national". The second cluster consists of documents coming from sources directly related to ASEAN and is subsequently referred to as "regional". The third cluster persists of press articles from newspapers which operate in the ASEAN area and is therefore referred to as "press". The analyzed material covers the time span from 2003 - the ratification of Bali Concord II, which confirmed the establishment of the ASEAN Community 2015 and subsequently the AEC - to 2015. Deductive reasoning, however, leaves us with limited options regarding the sample. Its size is thus limited. The analyzed units will not be restricted or shortened artificially. Thus, every message and text message from the material which are compatible with the categories can be captured.

In the light of the research questions' strong theoretical relation, it appears to be fruitful to not only develop inductive categories along the material, but also to derive deductive categories from the theoretical framework. Two categories are established based on the neofunctional spillover-logic and alongside central targets anchored in the AEC. Additionally, two categories following the logic of norm diffusion are presented to counter the first two categories. Five further categories are developed inductively according to the pre-analyzed material. 
Table 1. Categories along the Theoretical Framework

\begin{tabular}{ll}
\hline Category & Approach \\
\hline K1: Labor Migration of Skilled Workers & deductive (Neofunctionalism) \\
\hline $\begin{array}{l}\text { K2: Diminution of the Developmental Gap } \\
\text { Between ASEAN-6 and CLMV States }\end{array}$ & deductive (Neofunctionalism) \\
\hline K3: Human Capital & inductive \\
\hline K4: Creation of Cultural Awareness & inductive \\
\hline K5: Creation of Regional Identity & inductive \\
\hline K6: Knowledge-based Society & inductive \\
\hline K7: Economic Performance & Inductive \\
\hline K8: Rational Diffusion through Political & deductive (Norm Diffusion) \\
Learning & \\
\hline K9: Appropriate Acting & deductive (Norm Diffusion) \\
\hline
\end{tabular}

\section{Analysis}

The documents under consideration will be closely examined in order to find justifications and motivations for deeper integration in the education sector using the category system. The category system can additionally be summarized into three umbrella categories (UC) under which the nine categories can be subsumed after two rounds of pre-coding and reviewing the material.

1. Umbrella Category: Enhancing the economic performance by integrating in the education sector.

Subcategories: K1: Labor migration, K2: Development Gap, K3: Human Capital, K6: Knowledge-based Society, as well as K7: Economic Performance

2. Umbrella Category: Regional Awareness.

Subcategories: K4: Cultural Awareness, K5: Regional Identity

3. Umbrella Category: References to political learning or appropriate acting referring to the European Union.

Subcategories: K8: Political Learning, K9: Appropriate Acting

The analyzed material is constituted by sources from the above mentioned clusters. The national and also regional cluster mirror arguments and motivations from the elites, whereas the press cluster adds arguments and dispositions from the 


\section{Jan Gawron}

public sphere to ensure an acceptable degree of representativeness. The following chapter shows several considered text passages to illustrate the analysis.

\section{The National Cluster}

The state of source material in this cluster is not ideal. Nevertheless, various documents from different ministries, such as education and economy were available and analyzed. In order to illustrate the analysis, few examples of assigned text passage are shown below:

1. Malaysian Government News (2015): ASEAN Committed to a Harmonised Higher Education System. With 6,500 higher educational institutions and 12 million students in 10 nations, ASEAN is committed towards improving quality in education to achieve a harmonised higher education system in the region, said Malaysia's Second Education Minister Datuk Seri Idris Jusoh. He said higher education played a vital role in enhancing human resource development, fostering cultural understanding, generating knowledge and promoting networking, all of which had an impact on ASEAN's ability to be competitive globally.

2. The Government Public Relations Department (2014): Thailand Steps Up Educational Cooperation with ASEAN Partners. Dean of the Faculty of Education, Chulalongkorn University, Associate Professor Bancha Chalapirom, said that, in the exchange program, Thai-language teachers will be sent to help develop Thai language skills in other ASEAN nations, especially neighboring countries. At the same time, he said, teachers of other ASEAN languages will be accepted to teach students at Chulalongkorn University. The exchange program will create a new environment in which Thailand can become familiar with ASEAN matters and Thai students can learn more about the cultures of other ASEAN countries. [...] The Lao Deputy Minister of Education said that Laos is in the initial stage of using IT to help in education and would like to learn from Thailand, so that they move together toward the ASEAN Community in the future. The Lao Ministry of Education is in the process of conducting education reform to develop its education quality to the ASEAN standards. 


\section{Cultural Awareness + Regional Identity}

The categories K1 and K2 are not mentioned in the analyzed material. However, category K3 - part of umbrella category 1 related to economic performance - is the category which contains the most mentions in the material. $44 \%$ of the mentions are allotted to UC 2 which covers regional awareness. Messages concerning UC 3 cannot be found in the material.

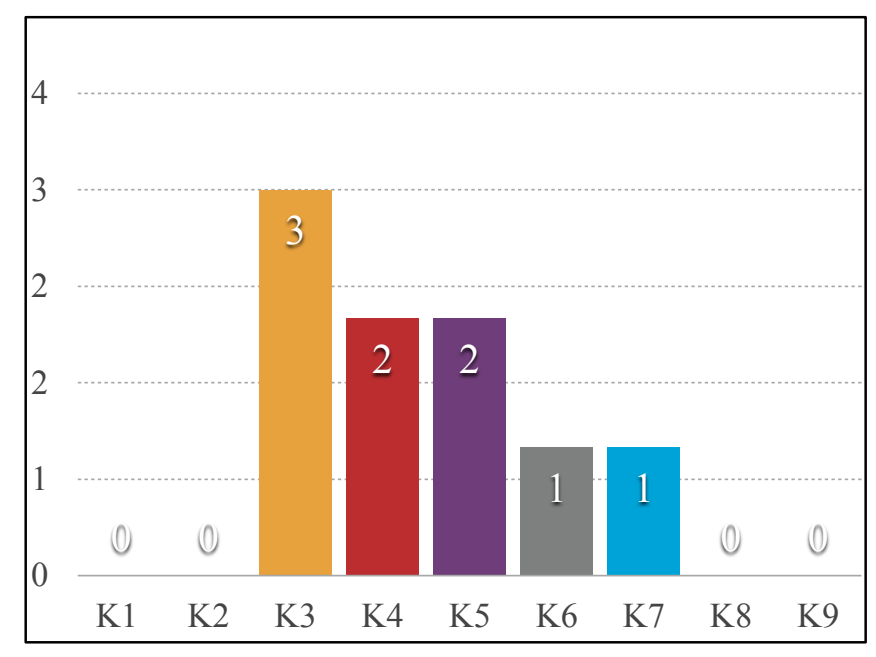

Figure 1. Frequency Distribution National Cluster

The fact that $44 \%$ of the allotted text passages correspond with UC2, which is not supported by any hypothesis presented here, should not be overlooked. However, the evidence here also shows that most text passages analyzed are assigned to UC1 (55\%) which supports neofunctionalist reasoning and H1. Norm diffusion arguments do not seem to be in play, as no text passage corresponds with categories K8 and K9, which were deduced from norm diffusion logic. Support for hypotheses H2a and H2b cannot be observed in this segment.

\section{The Regional Cluster}

In order to be applicable to this cluster, the sources must have a direct link to the regional organization. For example, various joint statements from the ASEAN Education Ministers Meeting (ASED; see ASEAN Secretariat, 2015), the Southeast Asian Ministers of Education Organization (SEAMEO), or the ASEAN 5-Year Work Plan on Education (2011-2015) are considered here: 
1. Joint Statement of the 5th ASED Meeting. The Ministers were pleased with the progress in AUN activities, including the projected implementation of the ASEAN Credit Transfer System (ACTS) in AUN Member Universities this year. The ACTS seeks to enhance and facilitate student mobility among AUN Member Universities, which is one of the targets to be achieved under the 'Free Flow of Skilled Labour' of the ASEAN Economic Community Blueprint.

2. ASEAN Secretariat: ASEAN 5-Year Work Plan on Education. Promoting ASEAN Awareness: ASEAN aims to build the ASEAN identity by promoting awareness and common values at all levels of society and in the education sector.

It is worth noting here that the high percentage of messages are assigned to UC 2 (K4: 18\% and K5: 18\%). Categories K1, K3 and K7 - which relate to economic performance - are also very frequently mentioned. Categories K8 and K9, which are deduced from norm diffusion research, do not seem to play an important role in the regional cluster.

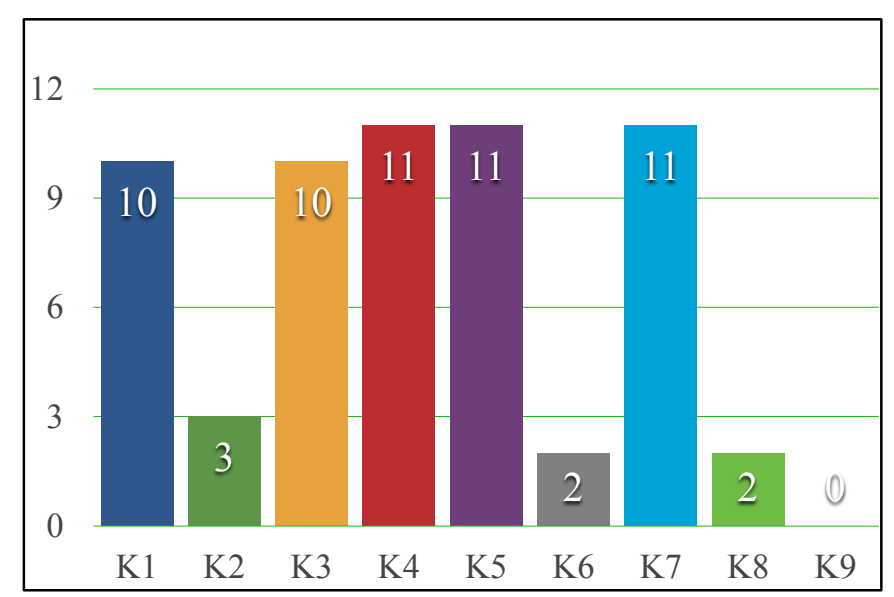

Figure 2. Frequency Distribution Regional Cluster

Again, UC1 is the most mentioned umbrella category. The evidence clearly supports hypothesis H1. UC2 is mentioned very frequently as well. And much like in the National Cluster, UC3 does not seem to be significant. 


\section{The Press Cluster}

Here, articles from newspapers are analyzed in order to add a public perspective. In order to fit the sample, sources must come from a newspaper that demonstrably operates in at least one ASEAN member country.

1. The Nation Thailand (2014): Moves to Boost Education. Ministers from the 10 ASEAN states held talks at the 8th ASEAN Education Ministers Meeting (8th ASED), held in Vientiane from September 8-13. The ministers' discussions focused in 'Future Considerations on the Post-2015 Vision', in which they identified priorities for the next five-year plan 2016-2020. The move is aimed at further narrowing the development gap on education and human-resource development among ASEAN countries, notably between older and newer member nations.

2. The Jakarta Post (2011): Promoting ASEAN Identity in Education. The benefit of the current integration process should not be targeted exclusively for economic purpose, but also to introduce a regional identity to each person in ASEAN. And education could be used to achieve this objective. [...] All we have to do is to start understanding our neighbors and communicating with them. We want to see a future where ASEAN is an inclusive community where the grassroots could also participate, not only elite institutions where politicians and high-profile figures make agreements in closed meeting rooms.

In the Press Cluster UC 3 also does not seem to play an integral role. Only 8\% of the included passages refer to $\mathrm{K} 8$, none to $\mathrm{K} 9$. Also, it is worth noting that the repeatedly high percentage (19\%) of passages are allotted to K5. K4, however, is less present with only 8\%. K1 contains most mentions (22\%) followed by K7 (19\%), which both belong to UC 1 . 


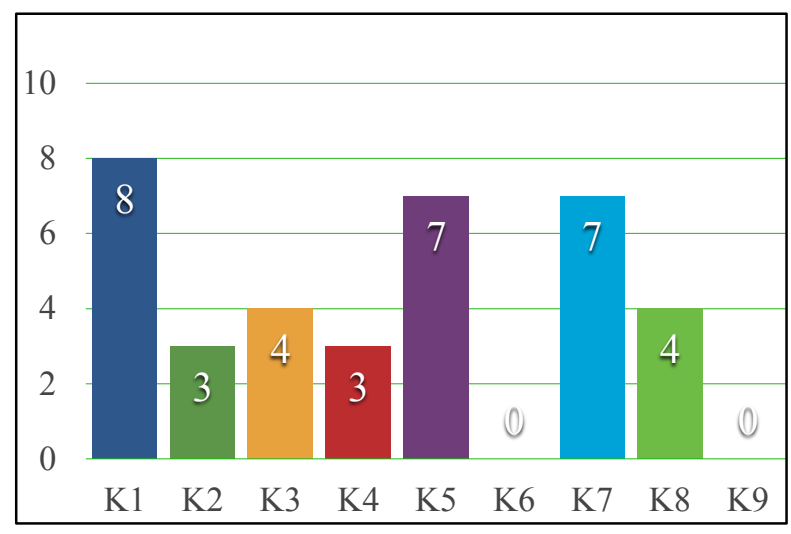

Figure 3. Frequency Distribution Press Cluster

In general, the same tendencies as in the two previous segments can be observed in the Press Cluster as well. The frequent mentioning of UC2 member category K5 is not explainable with the hypotheses presented here. Although being mentioned in this cluster, K8 and K9 do not seem to be significant categories. Moreover, categories which firm under UC1 are mentioned the most, A fact, which supports H1.

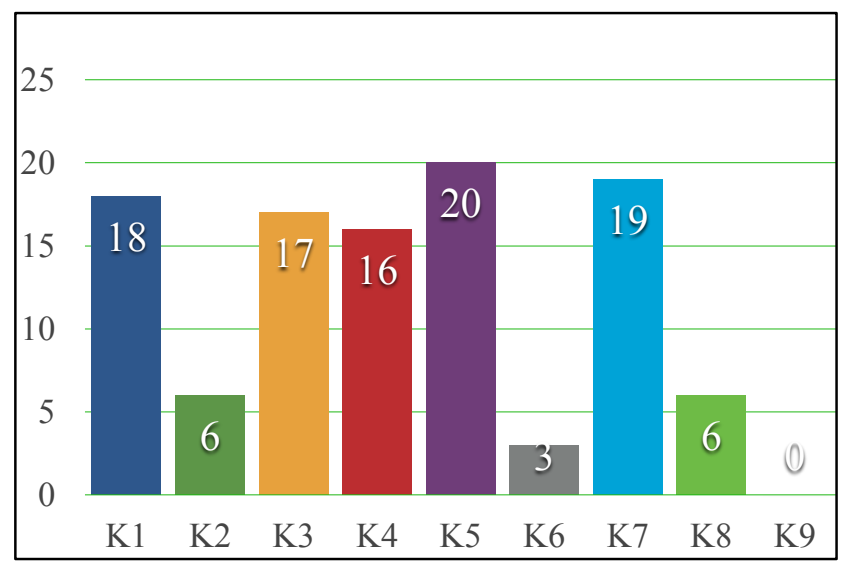

Figure 4. Total Frequency Distribution ${ }^{5}$

The most passages can be allotted to Category K5: Regional Identity - 19\% of the analyzed sample fit into this category. K7: Economic Performance and K1: Labor Migration follow second and third, respectively. K2: Development Gap (5\%), K3: Human Capital (16\%) and K6: Knowledge-based Society (3\%) complete UC1. K4: Cultural Awareness - K5's counterpart contains 15\% of the analyzed passages. Not a

5Exact distribution in percent: K1: 17,14 / K2: 5,71 / K3: 16,19 / K4: 15,24 / K5: 19,05 / K6: 2,86 / K7: 18,1 / K8: 5,71 / K9: 0,0. 
single passage fits into K9: Appropriate Acting and only $6 \%$ of the passages go into its co-category under UC3 (K8: Political Learning).

The results translate into the following UC-percentages: $60 \%$ of the passages fall upon UC 1 which represents economic performance. 36\% are allotted to UC 2 (Regional Awareness) and UC 3, standing for references to both political learning and appropriate acting contain $6 \%$ of the sample. UC1 is most mentioned in each of the three clusters. Despite this clear distribution it needs to be acknowledged that $\mathrm{K} 4$ and K5 are strongly represented in every cluster (except for the Press Cluster where only $8 \%$ of the passages fall upon $\mathrm{K} 4$ ).

\section{Discussion}

Looking at the analyzed material and the distribution of the assigned passages, it becomes apparent that $60 \%$ of the justifications and motivations for education integration are connected to migration of skilled labor, the narrowing of the developmental gap between ASEAN-6 and the CLMV states, the promotion of a knowledge-based society, as well as generally enhancing the economic performance. ${ }^{6}$ Hence, it can be deduced that functional appeals from the economic sector play a vital role to justify education integration. It becomes clear that arrangements need to be made in order to meet economic targets which are expressed in the AEC blueprint (see ASEAN Economic Community Blueprint in ASEAN Secretariat, 2008). The ASEAN State of Education Report, for example, states several measures that serve economic integration:

"To strengthen the economic pillar, it was agreed that there should be: (i) a national skills framework in each of the ASEAN Member States, as an incremental step towards the establishment of an ASEAN skills recognition framework; (ii) conditions supportive of greater cross-border mobility for students and skilled workers; (iii) an ASEAN competency-based occupational standard; and (iv) a common set of competency standards especially for technical and vocational education and training (TVET) as a basis for benchmarking with a view to promoting mutual recognition" (ASEAN State of Education Report, in ASEAN Secretariat, 2013, p. 14).

This shows that education integration does also play a role in achieving economic targets. This process can be called spill-over. Therefore hypothesis H1:

${ }^{6}$ See distribution in Figure 4. 
"Education Integration initiatives are spillovers from the economic sector" can be confirmed. This argumentation is additionally supported by the fact that in all three clusters the most passages fall upon umbrella category 1.

Moreover, the central research question can be explained and answered with the help of neofunctionalism's spillover component; Functional appeals for integration in the education sector are derived from economic integration measures. This assumption becomes strengthened when taking the hypotheses H2a: "Integration in the education sector is a result of political learning" and H2b: "Integration in the education sector is a result of appropriate acting" into account. Neither H2a, nor H2b can be confirmed. Category K8: Political Learning accounts for 6\% of the mentions found in the material. K9: Appropriate Acting cannot be found in the material at all. If the spillover is accepted as bearing the applicable concept to this issue, this point serves well as a starting point for a reflection about the eligibility of Neofunctionalism for this part of the integration process in ASEAN, as well as to answer the central research question.

Neofunctionalism postulates that integration depends on cooperation initiated by a high degree of interdependency in one sector which then spills over to others, rather than on specific national policies. This aspect cannot be detected easily in ASEAN's integration process. Decisive steps are usually decided in official meetings of the heads of states in order to boost national interests (Kim, 2014, p. 382). But at this point, it can also be argued that the tables have turned with the implementation of the AEC. National economic interest can absolutely be driven by functional appeals especially with regard to the AEC. Neofunctionalism generally asks how economic integration turns into political integration, or as Haas puts it: "Political integration follows economic integration immediately" (Conzelmann, 2006, p. 163; Haas, 1968, p. 311).

This development is accompanied by the dynamic spillover component. When looking at the entire course of the integration process in ASEAN since its foundation in 1967, the clear order "form follows function" does not hold true. If turning to the considered part of this process, however, at least the "expansive logic of sectoral integration" (Conzelmann, 2006, p. 166) can be ascertained when taking the AEC or economic integration in general as motivation for education integration into account. Further arguments for the application of Neofunctionalism in the context of the ASEAN 
integration process can be observed. For example, the overall focus on political elites (Kim, 2014, p. 378). But here, the focus lies on the eligibility of neofunctionalism as a theoretical framework for the question of justifications and motivations for deeper education integration.

The principle focus on the starting point of cooperation in more technical sectors is generally in accordance with Neofunctionalism. The lacking desire for supranational solutions can be explained with the degree of the elite's socialization, which is decisive for further vertical development (Dougherty \& Pfaltzgraff, 2001, p. 516; Kim, 2014, p. 388). The strongly functional justification for further sector-overlapping cooperation from elitist circles is also in accordance with the neofunctionalist argumentative logic (Dougherty \& Pfaltzgraff, 2001, p. 513). The analysis of the material supports this assumption. Most mentions fall upon UC1, both in the national and regional cluster, which represent the justifications and motivations of the political elites. $\mathrm{H} 1$ and also the central research question can be explained with the help of the spillover component.

As mentioned above already, H2a and H2b cannot be confirmed. Subsequently norm diffusion approaches do not offer explanation or further understanding of integration initiatives in the sector of integration. If anything, this only cements the confirmation of H1. Nevertheless, the frequent mentions of categories K4 and K5, summarized under UC2, cannot be ignored. K5 is the most mentioned category of all (19\%) and at least ranked second in each cluster. The creation of a regional identity with respect to all cultures of ASEAN member states is a declared goal. The ASEAN Work Plan on Education even formulates this as top priority:

"Priority 1 - Promoting ASEAN Awareness: ASEAN aims to build the ASEAN identity by promoting awareness and common values at all levels of society and in the education sector" (ASEAN 5 Year Work Plan on Education, in ASEAN Secretariat, 2012, p. 17).

None of the considered theoretical approaches offers a plausible explanation here. Only if regional identity is being understood as an act of socialization within the context of the EU, this result could be seen as a sign of norm diffusion. However, the emphasis of cultural awareness can rather be related to central codes of conduct; the respect for territorial sovereignty and non-interference with domestic issues of other member states. Furthermore, no clear references to the regional identity of the EU or 


\section{Jan Gawron}

its advantages can be detected in the material which could point to strategies of socialization or legitimation. The emphasis on respect for other states' cultures and a shared identity of the member states could also be seen as a low-cost alternative to actual, costly measurements for the development of integration in the education sector.

\section{Conclusion}

This chapter tried to detect justifications and motivations for integration in the education sector in the ASEAN area. This relatively new phenomenon in the course of the ASEAN integration process is an interesting case to study because no extensive scientific analysis has yet been written on the topic. Through the visible connection of the public sphere, facilitated through the Press Cluster as well as official ASEAN statements, a connection of education integration and economic integration can be observed. Therewith the central research question for functional appeals for education integration deriving from economic integration could be answered.

Justifications and motivations for further education integration have been presented on the basis of a content-structured content analysis with a following frequency analysis. Two major theoretical perspectives were presented to form a theoretical framework, from which three hypotheses were deduced. On the one hand Neofunctionalism as a classical theory of regional integration, which seeks to explain how cooperation spills over from one sector into another and propels regional integration further. H1: "Education Integration initiatives are spillovers from the economic sector" was derived from this argumentative logic. On the other hand, a rational, as well as a reflexive understanding of third generation norm diffusion research was introduced as the countering approach to Neofunctionalism.

Hypotheses H2a: "Integration in the education sector is a result of political learning." and $\mathrm{H} 2 \mathrm{~b}$ : "Integration in the education sector is a result of appropriate acting." were deduced. By classifying 40 documents into a category system which contains four deductive categories (K1, K2, K8, K9) and additional five inductive categories (K3, K4, K5, K6, K7), justifications and motivations for education integration could be presented in a structured way. Most passages were allotted to Umbrella Category 1, followed by UC2 and UC3. H1 has been confirmed on the basis of this categorization - pointing at the fact that $60 \%$ of the passages have been assigned 
to UC1. H2a and H2b, however, have to be negated. Thus, the central research question can be answered; Functional appeals for integration in the education sector derive from integration in the economic sector. Additionally, it can be noted that Neofunctionalism offers valuable input to the understanding of the Southeast Asian integration process. We can then conclude that ASEAN members' major interest lies in enhancing economic performances through strengthening the education sector, rather than emphasizing the education sector itself.

Furthermore, the frequent mentions of K4 and K5 should not be disregarded. None of the here presented theoretical perspectives offers viable explanations. It would be interesting to further apply Neofunctionalism to the context of different phases of the ASEAN integration process and to develop a more specific theoretical construct for the context of ASEAN. Moreover it would be insightful to analyze domestic debates concerning the constitution of interest of the political elite before they take it to the regional level, in order to determine in what way and to what extent they are driven by processes of diffusion and subsequently to understand the focus on cultural awareness and regional identity better. At this point, another research design is needed, which builds on these findings and then aims on understanding these processes better. Especially with regard to the future and further developments after the official implementation of the ASEAN Economic Community, as well as the progressing ASEAN-EU cooperation in the sector of education.

\section{References}

Acharya, A. (2009). Whose Ideas Matter: Agency and Power in Asian Regionalism. New York \& London: Cornell University Press.

ASEAN Secretariat. (2015). Education Ministers Meeting. Retrieved from http://www.asean.org/communities/asean- socio-cultural-community/ category/asean-education-ministers-meeting-ased

(2013). ASEAN State of Education Report. Retrieved from http://www.asean.org/images/resources/2014/Oct/ASEAN\%20State\%20of\% 20Education\%20Report\%202013.pdf . (2012) ASEAN 5 Year Work Plan on Education (2011-2015). Retrieved from http://de.scribd.com/ doc/116508108/ASEAN-5-Year-Education-Work-Plan 
. (2008). ASEAN Economic Community Blueprint. Retrieved from http://www.asean.org/archive/5187-10.pdf

. (2007). The ASEAN Charter. Retrieved from http://www.asean.org/archive/ publications/ASEAN- Charter.pdf

- (2003) Declaration of ASEAN Concorde II. Retrieved from http://www.asean.org/news/item/declaration-of-asean-concord-ii-bali concord-ii

. (1976) Treaty of Amity and Cooperation in Southeast Asia. Retrieved from http://www.asean.org/news/item/treaty-of-amity-and-cooperation-insoutheast-asia-indonesia-24-february-1976-3

(1967). The ASEAN Declaration.Retrieved from http://www.asean.org/news/item/the-asean-declaration-bangkok-declaration ASEAN University Network.(2015). EU-ASEAN Project. EU to Support Higher Education in ASEAN Region (EU SHARE). Retrieved from http://www.aunsec.org/aseanqaeuproject.php

Ashayagachat, A. (2012). AEC Pushed Back 12 Months. The Bangkok Post. Retrieved from: http:// www.bangkokpost.com/news/local/321914/aec-pushed-back12-months

Börzel, T. A.,\& Risse, T. (2000). When Europe Hits Home: Europeanization and Domestic Change. European Integration online Papers (EIoP) 4(15). Retrieved from http://eiop.or.at/eiop/pdf/ 2000-015.pdf

. (2009). The Transformative Power of Europe: The European Union and the Diffusion of Ideas. KFG Working Paper Series 1. Retrieved from http://www.polsoz.fu-berlin.de/en/v/transformeurope/publications/working _paper/WP_01_Juni_Boerzel_Risse.pdf

Braun, D.,\& Gilardi, F. (2006). Taking 'Galton's Problem' Seriously: Towards a Theory of Policy Diffusion. Journal of Theoretical Politics 18(3), 298-322.

Busse, N. (1999). Constructivism and Southeast Asia Security. The Pacific Review 12(1), 39-60.

Chia, S. Y., et al. (2009). Regional Market for Goods, Services, and Skilled Labour. In Plummer, M. G., \& Chia, S. Y. (Eds.), Realizing the Asean Economic Community: A Cromprehensive Assesment (pp.20-57). Singapore: Institute of Southeast Asian Studies. 
Conzelmann, T. (2006). Neofunktionalismus. In Schieder, S., \& Spindler, M. (Eds.), Theorien der Internationalen Beziehungen (2nd ed., pp.145-171). Opladen \& Farmington Hills: Barbara Budrich.

Delegation of the European Union to Indonesia, Brunei Darussalam and ASEAN. (2015). EU and ASEAN Start a New Programme on Harmonisation of ASEAN Higher Education. Retrieved from http://eeas.europa.eu/delegations/indonesia /press_corner/all_news/news/2015/20150506_01_en.htm

Deutsch, K. W., et al. (1957). Political Community and the North Atlantic Area. Princeton: Princeton University Press.

Di Maggio, P. J., \& Powell, W. W. (1982). The Iron Cage Revisited: Institutional Isomorphism and Collective Rationality in Organizational Fields. American Sociological Review, 48(2), 147-160.

Dougherty, J. E., \& Pfaltzgraff, R. L. (2001). Contending Theories of International Relations: A Comprehensive Survey. New York: Longman.

Feuer, H. N., \& Hornidge, A. (2015). Higher Education Cooperation in ASEAN: Building towards Integration or Manufacturing Consent? Comparative Education 51(3).

Finnemore, M., \& Sikkink, K. (1998). International Norm Dynamics and Political Change. International Organization, 52(4), 887-917.

Frenquest, J. (2015). Asean Economic Community 2015: Ready or Not, Here it Comes. The Bangkok Post. Retrieved from http://www.bangkokpost.com/learning/ work/454697/asean-economic-community-2015-ready-or-not-here-it-comes

Haas, E. B. (1958). The Uniting of Europe: Political, Social, and Economic Forces 19501957. Stanford: Stanford University Press. . (1961). International Integration: The European and the Universal Process. International Organization, 15(3), 366-92.

Hawkins, J. N. (2012). Regionalization and Harmonization of Higher Education in Asia. Asian Education and Development Studies, 1(1), 96-108.

Jetschke, A.,\& Lenz, T. (2011). Vergleichende Regionalismusforschung und Diffusion: Eine neue Forschungsagenda. Politische Vierteljahresschrift, 52(3), 448-474.

Jetschke, A.,\& Murray, P. (2012). Diffusing Regional Integration: The EU and Southeast Asia. West European Politics, 35(1), 174-191.

Jetschke, A.,\& Rüland, J. (2009). Decoupling Rhetoric and Practice: The Cultural Limits of ASEAN Cooperation. The Pacific Review, 22(2), 179-203. 
Keck, M. E., \& Sikkink, K. (1998). Activists beyond Borders: Advocacy Networks in International Politics. Ithaca: Cornell University Press.

Keo, K. (2012). Concern over Higher Education Quality as ASEAN Community Looms. University World News. Retrieved from http://www.universityworldnews.com/ article.php?story $=20120924142138123$

Keohane, R. O., \& Nye, J. S. (1977). Power and Interdependence: World Politics in Transition. New York: Harper Collins.

Kim, M. H. (2014). Integration Theory and ASEAN Integration. Pacific Focus, 29(3), 374-394.

Koh, A. (2007). Deparochializing Education: Globalization, Regionalization, and the Formation of an ASEAN Education Space. Discourse: Studies in the Cultural Politics of Education, 28(2), 179-195.

Kuckartz, U. (2012). Qualitative Inhaltsanalyse: Methoden, Praxis, Computerunterstützung. Weinheim: Beltz.

Lindberg, L. N. (1963). The Political Dynamics of European Economic Integration. Stanford: Stanford University Press.

Lindberg, L. N., \& Scheingold, S. A. (1970), Europe's Would-Be Polity. Englewood Cliffs: Prentis-Hall.

Malaysian Government News. (2015). ASEAN Committed to a Harmonized Higher Education System. Retrieved from http://www.lexisnexis.com/lnacui2api/auth /checkbrowser.do?ipcounter $=1 \&$ cookieState $=0 \&$ rand $=0.1972755361877886 \&$ bhcp $=1$

Mattli, W. (2005). Ernst Haas's Evolving Thinking on Comparative Regional Integration: of Virtues and Infelicities. Journal of European Public Policy, 12(2), 327-48.

Mayring, P. (2010). Grundlagen und Techniken. Basel: Beltz.

Narine, S. (2008). 40 Years of ASEAN: A Historical Review. The Pacific Review, 21(4), 411-429.

Neubauer, D. (2012). Higher Education Regionalization in Asia Pacific. Asian Education and Development Studies, 1(1), 11-17.

Radaelli, C. M. (2000). Whither Europeanization? Concept Stretching and Substantive change. European Integration Online Papers (EIoP) 4(8). Retrieved from http://eiop.or.at/eiop/texte/2000-008a.htm 
Ravenhill, J. (2008). Fighting Irrelevance: An Economic Community 'with ASEAN Characteristics'. The Pacific Review, 21(4), 469-488.

Risse, T., Ropp, S. C., \& Sikkink, K. (Eds.). (1999). The Power of Human Rights: International Norms and Domestic Change. Cambridge: Cambridge University Press.

Rosamond, B. (2005). The Uniting of Europe and the Foundation of EU Studies: Revisiting the Neofunctionalism of Ernst B. Haas. Journal of European Public Policy, 12(2), 237-254.

Rother, S. (2004). Normen, Identitäten und die Logik der Anarchie: Die ASEAN aus konstruktivistischer Perspektive. Freiburg i. Br.: Arnold Bergstraesser Institut.

Rüland, J. (2012). The Limits of Democratizing Interest Representation: ASEAN's Regional Corporatism and Normative Challenges. European Journal of International Relations.

Schimmelfennig, F. (2008). Internationale Politik. Paderborn: Schöningh.

Schmitter, P. C. (2004). Neo-Neo-Functionalism?.In Wiener, A.,\& Dietz, T. (Eds.), European Integration Theory (pp.45-74). Oxford: Oxford University Press.

Schreier, M. (2014). Varianten Qualitativer Inhaltsanalyse: Ein Wegweiser im Dickicht der Begrifflichkeiten. Forum Qualitative Sozialforschung 14(1). Retrieved from http://www.ssoar.info/ssoar/ handle/document/37708 . (2012).Qualitative Content Analysis in Practice. London: Sage.

The Bangkok Post. (2013). Time to Spend Money Where It's Needed. Retrieved from http:// www.lexisnexis.com/lnacui2api/auth/checkbrowser.do?ipcounter=1\& cookieState $=0$ \&rand $=0.8576234561176715 \&$ bhcp $=1$

The Government Public Relations Department. (2014). Thailand Steps Up Cooperation $\begin{array}{llll}\text { with } & \text { PSEAN } & \text { Rartners. }\end{array}$ http://thailand.prd.go.th/ewt_news.php?nid=536\&filename=index

The Jakarta Post.(2011). Promoting ASEAN identity in Education. Retrieved from http://www.thejakartapost.com/news/2011/05/19/promoting-aseanidentity-education.html

The Nation Thailand. (2014). Moves to Boost Education Cooperation Ahead of AEC. Retrieved from http://www.nationmultimedia.com/national/Moves-to-boosteducation-cooperation-ahead-of-AEC-30243272.html 